\title{
Trophic structure of rocky intertidal communities: response to wave action and implications for energy flow
}

\author{
C. D. McQuaid \& G. M. Branch \\ Zoology Department, University of Cape Town, Rondebosch 7700, South Africa
}

\begin{abstract}
The influence of physical factors on the trophic structure of rocky intertidal communities in the Cape of Good Hope was investigated by examining species composition and biomass on shores subject to different conditions of substratum, sea temperature and wave exposure. Biomass of herbivores on shores with an unstable substratum was particularly high while the sessile filter-feeders and algae were impoverished, but actual rock type did not affect trophic structure. Sea temperature influenced species composition but not trophic structure which was most strongly affected by the degree of wave exposure. Exposure influenced both vertical distribution of biomass and trophic composition of total biomass. Total biomass showed a simple decrease upshore on sheltered shores but the pattern was more complex with greater exposure. Filter-feeders, carnivores and omnivores all exhibited significantly higher biomass under exposed conditions. Consequently the balance between consumers and primary producers shifted, implying alterations in the net balance between importation and exportation of production between these communities and the inshore marine system. The addition of huge filter-feeder components to the intertidal system resulted in significantly higher total biomass under exposed conditions. This allows the importation of production from the water column to a community in which consumers exhibit considerably higher standing crops than primary producers. Benthic carnivores exhibited a positive correlation with filter-feeder biomass. It is therefore suggested that domination of exposed shores by sessile filter-feeders and of sheltered shores by algae and mobile herbivores may explain divergent views in the literature on the relative importance of competition and disturbance/predation to community structure on rocky shores.
\end{abstract}

\section{INTRODUCTION}

Much recent ecological research on rocky shores and shallow subtidal regions (especially kelp beds) has involved extensive work on energy flow in an attempt to illuminate functional relations within the communities present. The general approach in such studies has been to identify the most abundant species present and to derive detailed energy budgets for them (e.g. Greenwood 1980, Shafir \& Field 1980, Griffiths 1981, Koop \& Field 1981).

Wulff \& Field (1983) have shown that energetic pathways in a kelp-bed community change under upwelling and downwelling conditions. In the present study we examine the trophic structure of intertidal communities which experience different physical conditions. We present data on biomass of the flora and fauna of rocky shores, subject to a range of conditions including different degrees of exposure to wave action, different temperature regimes and different kinds of rocky substrata. The influence of these factors on trophic structure and thus on fundamental patterns of energy flow through the communities is analysed. Physical factors appear to establish basic patterns of energy flow at a trophic level so that different trophic compartments predominate under different conditions (McQuaid 1980). Thus the balance between component trophic compartments may be altered and will determine whether a particular intertidal community will, overall, import or export energy. Species composition of these trophic compartments is, however, controlled by biogeographic considerations and the influence of chance recruitment of pelagic larvae.

Wave action is often considered to have an important influence on intertidal communities and the importance of degree of wave exposure to community structure has long been recognised (Lewis 1964, Stephenson \& Stephenson 1972). Comparisons are frequently 
made between exposed and sheltered shores (e.g. Seapy \& Littler 1978, MacLachlan et al. 1981) and biological exposure scales have been developed to define wave action on the basis of the biota (Ballantine 1961, Lewis 1964) but such work has, in the past, been of a qualitative nature. We now compare exposed and sheltered rocky shores on a quantitative basis and examine the influence of wave exposure on the trophic structure of intertidal communities as a whole, including implications for energy flow between the intertidal and adjacent ecosystems.

\section{METHODS}

To examine the influence of physical factors on the trophic structure of intertidal communities 12 rocky shores in the Cape of Good Hope, South Africa, were selected to cover a range of conditions of substratum type, sea temperature and degree of wave exposure (Table 1; Fig. 1). Six of the shores were subjectively rated as being 'exposed' on the basis that they directly faced the prevailing wave direction, and the remaining 6 were rated as 'sheltered' because they were in bays

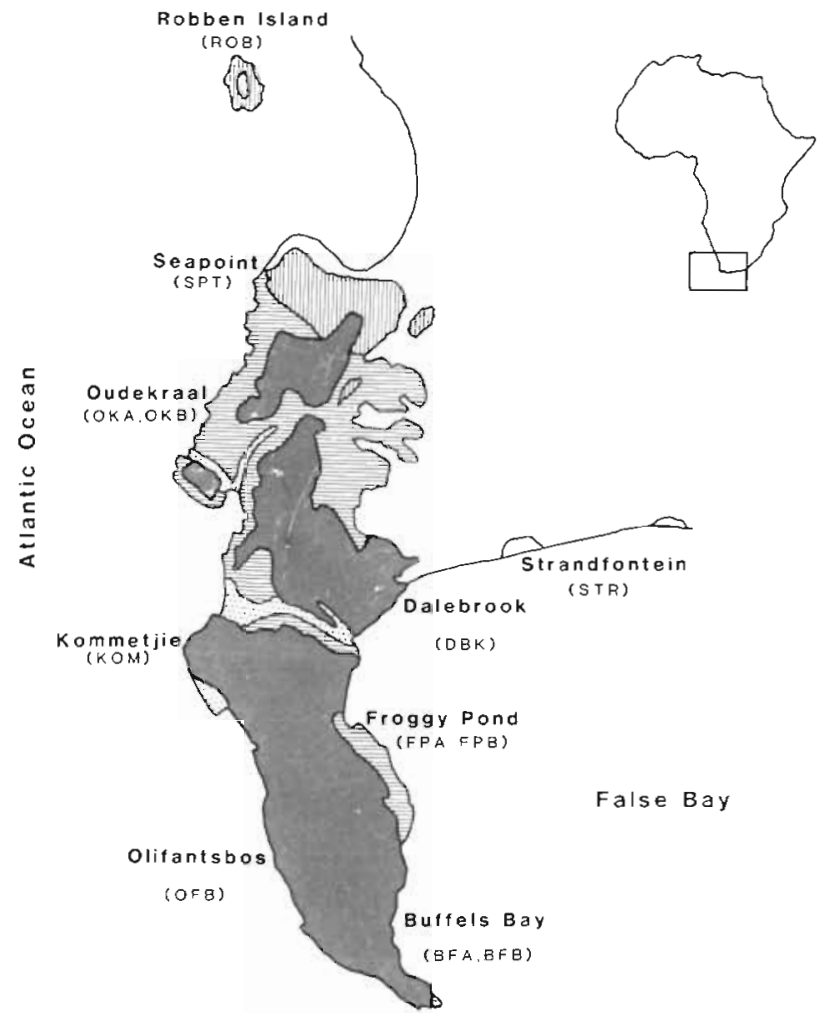

Fig. 1. Study sites in the Cape of Good hope. Names abbreviated in brackets. Rock types: solid shading - Table Mountain sandstone; horizontal lines - Cape granite; vertical lines Malmesbury shale; open circles - unconsolidated beach rock; dots - sand or were protected by headlands. The shores were rated prior to any analysis of the biota to avoid subjective bias. It should be noted that wave action in the Cape of Good Hope is generally severe; the exposed shores would be rated as extremely exposed in a European context, the sheltered shores as moderately exposed (Hawkins pers. com.). Of the 6 exposed and 6 sheltered shores, 3 of each lay in False Bay on the warm east coast of the Cape Peninsula, and 3 on the cold west coast. Mean monthly sea temperatures in False Bay range from 16 to $19^{\circ} \mathrm{C}$ in summer and from 12 to $14^{\circ} \mathrm{C}$ in winter. The west coast has lower temperatures: 11 to $13^{\circ} \mathrm{C}$ in winter and as low as $9^{\circ} \mathrm{C}$ in summer due to frequent upwelling (Fricke \& Thum 1979).

The substratum at Strandfontein consists of very soft, unconsolidated beach rock which erodes into many pools and hollows. The substrata of the remaining shores comprised Table Mountain Sandstone, Cape Granite or Malmesbury Shale. The sandstone is hard and chemically very stable with a small grain size. It weathers slowly in almost horizontal beds, forming broad beaches with a gentle slope. Cape Granite is coarse-grained and very hard, occurring as huge rounded boulders with a rough surface. Malmesbury shale has a very small grain size and weathers in jagged parallel ridges sloping gently downshore.

Each shore was mapped, using aerial photographs and field observations, into a mosaic of component zones and sub-zones, and each of these was sampled by collecting all organisms in duplicate $0.25 \mathrm{~m}^{2}$ quadrats. Large species or those exhibiting markedly clumped distributions were sampled separately using $1 \mathrm{~m}$ wide belt transects. Biomass values are expressed as shell-free dry weights. Heavily calcified species were acidised using $1 \mathrm{M} \mathrm{HNO}_{3}$ and dried to constant weight at $60^{\circ} \mathrm{C}$. Species biomass values were then summed into trophic compartments for each zone on each shore. Data for tide pools were omitted from this analysis, as pools do not conform to normal vertical gradients of physical conditions. The biomasses of trophic compartments for each shore as a whole were calculated from the values measured for each zone, weighted according to the proportion each zone formed of the entire shore (further details in McQuaid \& Branch 1984). Comparisons of trophic biomass on different shores were made by t-tests.

\section{RESULTS}

\section{Intershore comparisons}

Table 1 gives the number of species in each trophic compartment on each shore while data on total biomass on each shore and the contribution of each 
Table 1. Physical conditions and number of species in each trophic compartment on the 12 shores examined. WC: west coast cold water sites; FB: False Bay warm water sites; MS: Malmesbury Shale; CG: Cape Granite; TMS: Table Mountain Sandstone; BR: unconsolidated beach rock. Asterisks: beaches of unstable, small boulders. Abbreviations for shores as in Fig. 1

\begin{tabular}{|c|c|c|c|c|c|c|c|c|c|c|c|c|c|c|}
\hline \multirow[b]{3}{*}{ Temp. regime } & \multicolumn{7}{|c|}{ Exposed shores } & \multicolumn{7}{|c|}{ Sheltered shores } \\
\hline & SPT & $\mathrm{ROB}$ & OKB & FPB & DBK & STR & Mean & OKA & OFB & $\mathrm{KOM}$ & $B F A$ & $\mathrm{BFB}$ & FPA & Mean \\
\hline & WC & WC & WC & $\mathrm{FB}$ & FB & $\mathrm{FB}$ & & WC & WC & WC & $\mathrm{FB}$ & FB & FB & \\
\hline Substratum & MS & MS & $\mathrm{CG}$ & CG & TMS & $B R$ & & $\mathrm{CG}^{\cdot}$ & TMS & TMS & TMS & TMS $^{*}$ & CG & \\
\hline Macroalgae & 18 & 16 & 9 & 10 & 24 & 12 & 14.83 & 16 & 19 & 18 & 9 & 3 & 16 & 13.50 \\
\hline Herbivores & 24 & 21 & 16 & 17 & 31 & 22 & 21.83 & 12 & 23 & 30 & 27 & 20 & 25 & 22.83 \\
\hline Filter-feeders & 7 & 8 & 8 & 20 & 19 & 12 & 12.33 & 2 & 11 & 8 & 9 & 7 & 19 & 9.33 \\
\hline Omnivores & 4 & 4 & 4 & 2 & 2 & 3 & 3.17 & 0 & 2 & 0 & 2 & 2 & 3 & 1.50 \\
\hline Detritivores & 7 & 8 & 8 & 6 & 10 & 6 & 7.50 & 2 & 6 & 8 & 5 & 4 & 7 & 5.33 \\
\hline Scavengers & 18 & 13 & 12 & 16 & 21 & 17 & 16.17 & 9 & 17 & 26 & 20 & 15 & 19 & 17.67 \\
\hline Carnivores & 20 & 20 & 21 & 27 & 30 & 16 & 22.83 & 3 & 23 & 28 & 20 & 12 & 28 & 19.00 \\
\hline Total & 98 & 90 & 81 & 98 & 137 & 88 & 98.67 & 44 & 101 & 118 & 90 & 63 & 117 & 88.83 \\
\hline
\end{tabular}

trophic compartment to total biomass are presented in Table 2. There are 2 main points with regard to the number of species present. Firstly, some trophic compartments contain relatively few species: in particular the sessile filter-feeders and macroalgal compartments contain significantly fewer species than the mobile herbivores and carnivores (t-test: $\mathrm{P}<0.01$ ). Secondly, there are no significant differences between the number of species in each compartment on exposed and on sheltered shores. Furthermore, there is no correlation between the number of species present and total biomass, nor between the number of species in a trophic compartment and its contribution towards total biomass. T-tests were carried out to compare both total and trophic biomass on shores subjected to different physical conditions. The 2 shores composed of small boulders (Oudekraal A, Buffels Bay B) exhibited markedly lower total biomass than the remaining shores $(P<0.01)$. Algae and sessile filter-feeders in particular were extremely sparse on these 2 shores, presumably due to instability of the substratum. While actual biomass of the mobile herbivores remained similar to that of other shores, Oudekraal A and Buffels Bay B were unique in that the contribution of herbivores to total biomass was greater than that of any other trophic group (51.73\%, $42.37 \%$; Table 2$)$.

Further comparisons of total and trophic biomass, using t-tests, were carried out between warm and cold coast shores, between exposed and sheltered shores and between igneous and sedimentary shores. The

Table 2. Weighted mean biomass $\left(\mathrm{g} \mathrm{m}^{-2}\right)$ and percentage of total biomass (lower figures) formed by trophic compartments

\begin{tabular}{|c|c|c|c|c|c|c|c|c|c|c|c|c|c|c|}
\hline \multirow{4}{*}{ Prımary producers } & \multicolumn{7}{|c|}{ Exposed beaches } & \multicolumn{7}{|c|}{ Sheltered beaches } \\
\hline & SPT & $\mathrm{ROB}$ & $\mathrm{OKB}$ & FPB & DBK & STR & Mean & OKA & $\mathrm{KOM}$ & OFB & BFA & $\mathrm{BFB}$ & FPA & Mean \\
\hline & 457.26 & 232.12 & 297.51 & 710.02 & 304.17 & 197.10 & 365.79 & 27.67 & 233.16 & 282.18 & 334.68 & 35.24 & 488.50 & 233.57 \\
\hline & 81.27 & 50.31 & 31.01 & 33.70 & 21.23 & 38.30 & 36.8 & 46.92 & 72.56 & 85.29 & 86.42 & 31.16 & 89.79 & 79.92 \\
\hline \multirow[t]{2}{*}{ Herbivores } & 37.13 & 44.78 & 32.43 & 26.65 & 48.23 & 122.23 & 51.90 & 30.49 & 66.12 & 45.85 & 28.65 & 46.78 & 17.19 & 39.18 \\
\hline & 6.60 & 9.71 & 3.38 & 1.25 & 3.67 & 24.22 & 5.13 & 51.73 & 20.50 & 13.86 & 7.59 & 42.37 & 3.02 & 13.40 \\
\hline \multirow[t]{2}{*}{ Filter-feeders } & 43.81 & 171.83 & 580.19 & 1361.22 & 1058.34 & 172.18 & 564.60 & 0.34 & 15.30 & 0.52 & 17.27 & 9.52 & 18.97 & 10.32 \\
\hline & 7.79 & 37.24 & 60.47 & 63.6 & 73.86 & 33.46 & 55.86 & 0.58 & 4.76 & 0.15 & 4.46 & 8.42 & 3.49 & 3.53 \\
\hline \multirow[t]{2}{*}{ Omnivores } & 6.04 & 5.85 & 6.86 & 13.60 & 4.03 & 2.37 & 6.46 & 0.26 & 0.00 & 0.25 & 0.27 & 0.03 & 0.14 & 0.16 \\
\hline & 1.07 & 1.32 & 0.76 & 0.12 & 0.16 & 0.93 & 0.64 & 0.44 & 0.10 & 0.02 & 0.55 & 4.96 & 1.07 & 0.06 \\
\hline \multirow[t]{2}{*}{ Detritivores } & 4.42 & 0.39 & 0.37 & 2.65 & 2.25 & 4.78 & 2.48 & 0.04 & 0.31 & 0.07 & 2.12 & 5.61 & 5.84 & 2.33 \\
\hline & 0.79 & 0.03 & 0.003 & 0.12 & 0.09 & 0.02 & 0.24 & 0.07 & 0.10 & 0.02 & 0.03 & 0.24 & 0.17 & 0.80 \\
\hline \multirow[t]{2}{*}{ Scavengers } & 7.60 & 1.28 & 8.86 & 13.92 & 6.97 & 1.84 & 6.75 & 0.14 & 5.30 & 1.53 & 2.49 & 10.52 & 8.50 & 4.75 \\
\hline & 1.35 & 0.28 & 0.92 & 0.65 & 0.49 & 0.36 & 0.67 & 0.24 & 1.65 & 0.46 & 0.64 & 9.30 & 1.56 & 1.62 \\
\hline \multirow[t]{2}{*}{ Carnivores } & 6.35 & 5.10 & 33.18 & 11.81 & 7.11 & 13.95 & 12.92 & 0.01 & 1.07 & 0.47 & 1.19 & 4.08 & 4.92 & 1.96 \\
\hline & 1.13 & 1.11 & 3.46 & 0.55 & 0.50 & 2.71 & 1.28 & 0.02 & 0.33 & 0.14 & 0.31 & 3.61 & 0.90 & 0.67 \\
\hline \multirow[t]{2}{*}{ Total } & 562.60 & 461.36 & 959.40 & 2139.87 & 1432.86 & 514.63 & 1010.90 & 58.94 & 321.27 & 330.88 & 387.25 & 113.08 & 544.06 & 292.27 \\
\hline & 100 & 100 & 100 & 100 & 100 & 100 & 100 & 100 & 100 & 100 & 100 & 100 & 100 & 100 \\
\hline
\end{tabular}


only significant differences found were in exposed/ sheltered comparisons. Filter-feeder and omnivore biomasses were both significantly higher on exposed shores $(\mathrm{P}<0.01)$ as were carnivore and total biomasses $(P<0.05)$. Excluding the 2 boulder beaches (Oudekraal A, Buffels Bay B), sheltered shores were dominated by primary producers which formed between 70 and $90 \%$ of the total biomass (mean algal biomass being 200 to $300 \mathrm{~g} \mathrm{~m}^{-2}$ ). Herbivores formed the largest faunal component (mean $68.72 \%$ of faunal biomass; 17 to $66 \mathrm{~g} \mathrm{~m}^{-2}$ ) while filter-feeder biomass was very small $\left(0.3\right.$ to $\left.19 \mathrm{~g} \mathrm{~m}^{-2}\right)$ forming an average of $16.46 \%$ of faunal biomass. Biomasses of the remaining trophic compartments were still lower. Sheltered shores are thus dominated by algae and herbivores with filterfeeder biomass low but still forming the third largest component.

On exposed shores animals frequently dominated, primary producers making up on average only $37 \%$ of the total biomass. Filter-feeders (44 to $6,600 \mathrm{~g} \mathrm{~m}^{-2}$ ) formed a much larger proportion of total biomass averaging $75 \%$ of faunal biomass and $56 \%$ of the total biomass contributing even more than the algae on 3 of the shores. Algal biomass was not significantly different from that of sheltered shores, nor was the biomass of herbivores ( 26 to $52 \mathrm{~g} \mathrm{~m}^{-2}$ ), although on exposed shores it formed a smaller proportion of faunal biomass (mean $17.38 \%$ ) due to the preponderance of filter-

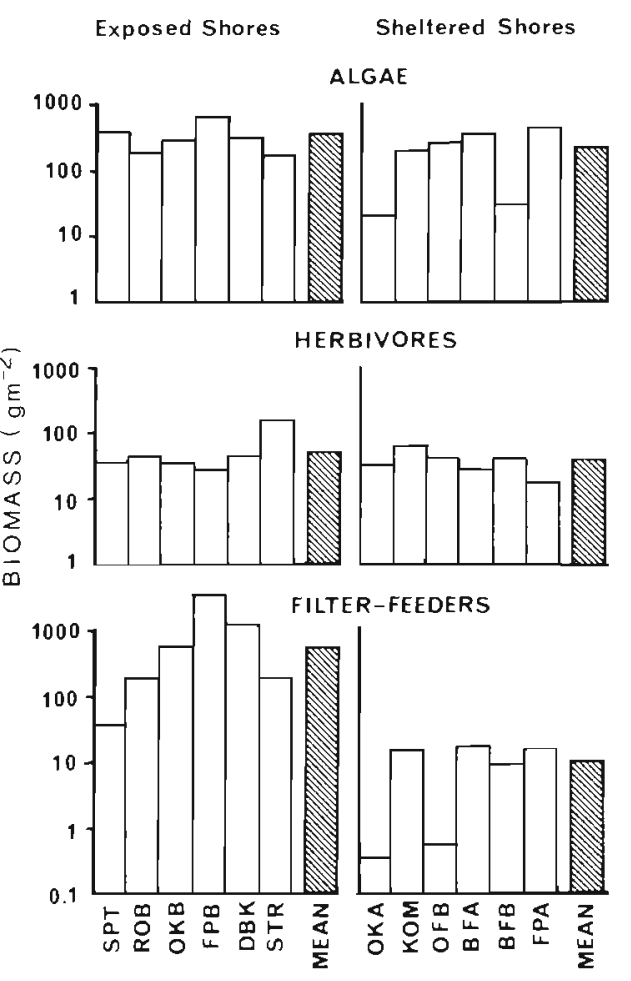

Fig. 2. Biomass of macroalgae, herbivores and filter-feeders (meaned for each shore) on exposed and sheltered beaches feeders. Carnivores and omnivores contributed minimally to the total biomass (3.18 and $1.90 \%$ respectively of faunal biomass) but both compartments exhibited significantly greater biomass under exposed conditions. Fig. 2 illustrates weighted mean biomasses for the 3 major trophic compartments (algae, herbivores and filter-feeders) on exposed and sheltered shores.

Exposed shores are thus distinct from sheltered shores in trophic structure. The species composition of the trophic compartments, however, was controlled by factors influencing their biogeography (including sea temperature), and different species dominated on the 2 coasts of the Cape Peninsula (McQuaid \& Branch 1984). As filter-feeders account for most of the differences in trophic structure their species composition is given in more detail in Table 3 to illustrate this effect. On the west coast the low-shore zones (sublittoral fringe, cochlear and sometimes lower balanoid) were dominated by the barnacle Octomeris angulosa and the bivalve Aulacomya ater. Upper-shore zones (mid and upper balanoid) were dominated by the barnacle Tetraclita serrata. On the warmer False Bay coast, lowshore zones were dominated by the tunicate Pyura stolonifera and the mussels $A$. aterand Perna perna. At Dalebrook mussels were less important and $O$. angulosa was abundant in the subtidal fringe. Mid and upper zones were again dominated by $T$. serrata and occasionally $O$. angulosa.

\section{Vertical zonation of trophic compartments}

Fig. 3 and 4 give shore profiles indicating the vertical distribution of trophic compartment biomass averaged for sheltered and exposed shores respectively. On sheltered shores there was a decrease in total biomass in an upshore direction while on exposed shores this trend was interrupted by a sharp increase in biomass in the upper balanoid zone to levels comparable to those in the sublittoral fringe. This increase was mainly due to a large biomass of filter-feeders in this zone. Filterfeeder biomass was generally low on sheltered shores and concentrated in the sublittoral fringe and middle balanoid zone. There was a similar pattern of low- and upper-shore peaks of filter-feeder biomass on exposed shores but the upper-shore populations occurred at vertically higher levels than on sheltered shores and the biomass values were orders of magnitude greater.

Although there was no significant difference in total macroalgal biomass on exposed and sheltered shores the vertical distribution of biomass differed. On sheltered shores algal biomass simply decreased upshore. With greater exposure algal biomass increased in the lower, mid and upper balanoid zones but farther downshore other factors resulted in a decrease in biomass. In 
Table 3. Composition of filter-feeder biomass in zones of high density on exposed shores, expressed as percentages of total filterfeeder biomass in each zone

\begin{tabular}{|c|c|c|c|c|c|c|c|c|c|c|}
\hline & \multirow[b]{2}{*}{ Shore } & \multirow[b]{2}{*}{ Zone } & \multicolumn{2}{|c|}{ Mussels } & \multirow[b]{2}{*}{$\begin{array}{c}\text { Balanus } \\
\text { algicola } \\
\%\end{array}$} & \multirow{2}{*}{$\begin{array}{c}\text { Barnacles } \\
\text { Octomeris } \\
\text { angulosa } \\
\%\end{array}$} & \multirow[b]{2}{*}{$\begin{array}{c}\text { Tetraclita } \\
\text { serrata } \\
\%\end{array}$} & \multirow{2}{*}{$\begin{array}{c}\text { Tunicates } \\
\text { Pyura } \\
\text { stolonifera } \\
\%\end{array}$} & \multirow[b]{2}{*}{$\begin{array}{c}\text { Total } \\
\%\end{array}$} & \multirow{2}{*}{$\begin{array}{c}\text { Filter- } \\
\text { feeder } \\
\text { biomass } \\
\left(\mathrm{g} \mathrm{m}^{-2}\right)\end{array}$} \\
\hline & & & $\begin{array}{c}\text { Aulacomya } \\
\text { ater } \\
\%\end{array}$ & $\begin{array}{l}\text { Perna } \\
\text { perna } \\
\%\end{array}$ & & & & & & \\
\hline \multirow{11}{*}{$\begin{array}{l}\text { WEST } \\
\text { COAST }\end{array}$} & SPT & Cochlear & 43.23 & & & 56.77 & & & 100.00 & 266 \\
\hline & & L. balanoid & 91.23 & & & & & & 91.23 & 57 \\
\hline & & U. balanoid & & & & 21.05 & 78.98 & & 100.00 & 19 \\
\hline & $\mathrm{OKB}$ & Fringe & 99.30 & & & & & & 99.30 & 1283 \\
\hline & & M. balanoid & 14.51 & & & 85.49 & & & 100.00 & 689 \\
\hline & & U. balanoid & 1.73 & & & & 98.27 & & 100.00 & 405 \\
\hline & $\mathrm{ROB}$ & Cochlear & 59.69 & & & 40.31 & & & 100.00 & 191 \\
\hline & & L. balanoid 1 & 50.15 & & & 49.26 & & & 99.41 & 339 \\
\hline & & L. balanoid 2 & 100.00 & & & & & & 100.00 & 338 \\
\hline & & M. balanoid & 1.33 & & & 96.22 & 0.82 & & 98.37 & 978 \\
\hline & & U. balanoid & & & & & 100.00 & & 100.00 & 155 \\
\hline \multirow{12}{*}{$\begin{array}{l}\text { FALSE } \\
\text { BAY }\end{array}$} & FPB & Fringe & 33.89 & 17.78 & 6.69 & 3.77 & & 36.40 & 98.53 & 478 \\
\hline & & L. balanoid & 28.26 & 11.59 & 56.52 & & & & 96.37 & 138 \\
\hline & & U. balanoid & 1.07 & & & 98.79 & 0.14 & & 100.0 & 6533 \\
\hline & DBK & Fringe 1 & 0.11 & & & 16.60 & & 83.09 & 99.81 & 3614 \\
\hline & & Fringe 2 & 0.53 & 2.67 & & 56.80 & & 37.87 & 97.87 & 375 \\
\hline & & M. balanoid & & & & 0.90 & 98.65 & & 99.55 & 222 \\
\hline & & U. balanoid & & & & & 100.00 & & 100.00 & 317 \\
\hline & STR & Fringe & 3.75 & 39.25 & & & & 57.00 & 100.00 & 293 \\
\hline & & L. balanoid & 39.62 & 51.15 & & & & & 90.77 & 26 \\
\hline & & M. balanoid & & & & & 99.42 & & 99.42 & 173 \\
\hline & & U. balanoid 1 & & & & & 100.00 & & 100.00 & 267 \\
\hline & & U. balanoid 2 & & & & & 100.00 & & 100.00 & 377 \\
\hline
\end{tabular}

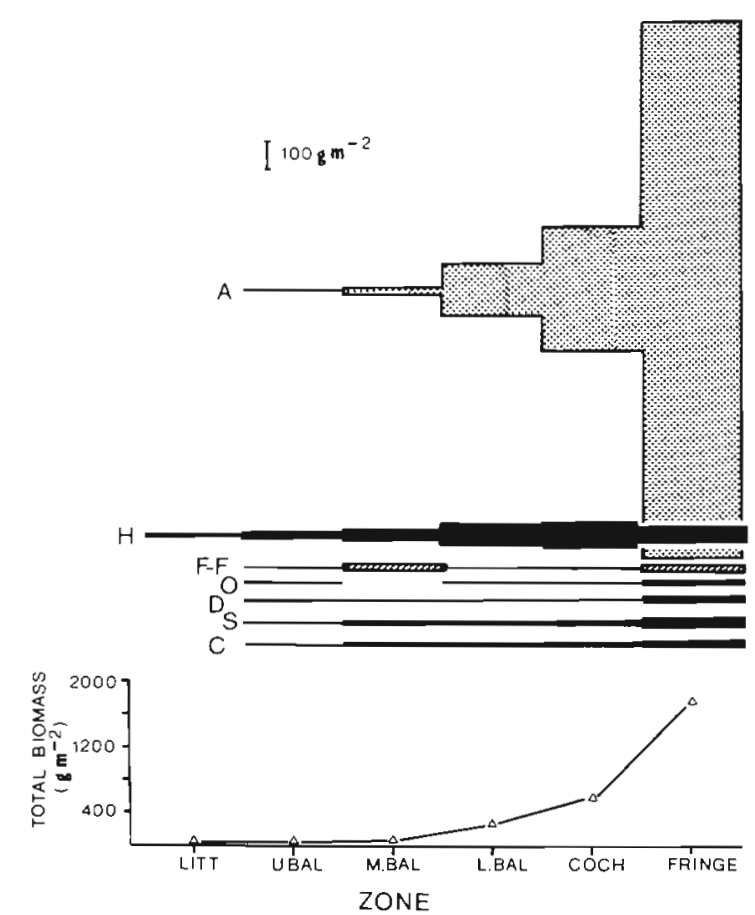

Fig. 3. Vertical distribution of total and trophic compartment biomass on sheltered shores. A: algae; $\mathrm{H}$ : herbivores; F-F: filter-feeders; O: omnivores; D: detritivores; S: scavengers; C: carnivores the cochlear zone density of the limpet Patella cochlear was much higher than on sheltered shores (Branch 1975) and intensive grazing resulted in a dramatic decrease in algal cover. Filter-feeder biomass in the sublittoral fringe was high and there was a decrease in algal biomass relative to that on sheltered shores, probably as a consequence of competition for space. Except for the cochlear zone there was no apparent correlation between herbivore and macroalgal biomass and herbivore biomass was frequently high in zones where macroalgae are seasonally or permanently absent.

Amongst the minor trophic compartments trends of vertical zonation were less obvious, but the biomass of carnivores did correlate positively with that of filterfeeders (Fig. 5) and was greatest in the sublittoral fringe and the upper balanoid on exposed shores (Fig. 4). An indirect relation is implied here as well as a direct one. Some whelks feed directly on barnacles and mussels but other carnivores such as errant polychaetes feed on smaller species sheltering among the filter-feeders as well as on the juveniles of some filter-feeders. Dense beds of filter-feeders offer many microhabitats for small species leading to an increase in species richness in these zones (McQuaid 1980). 


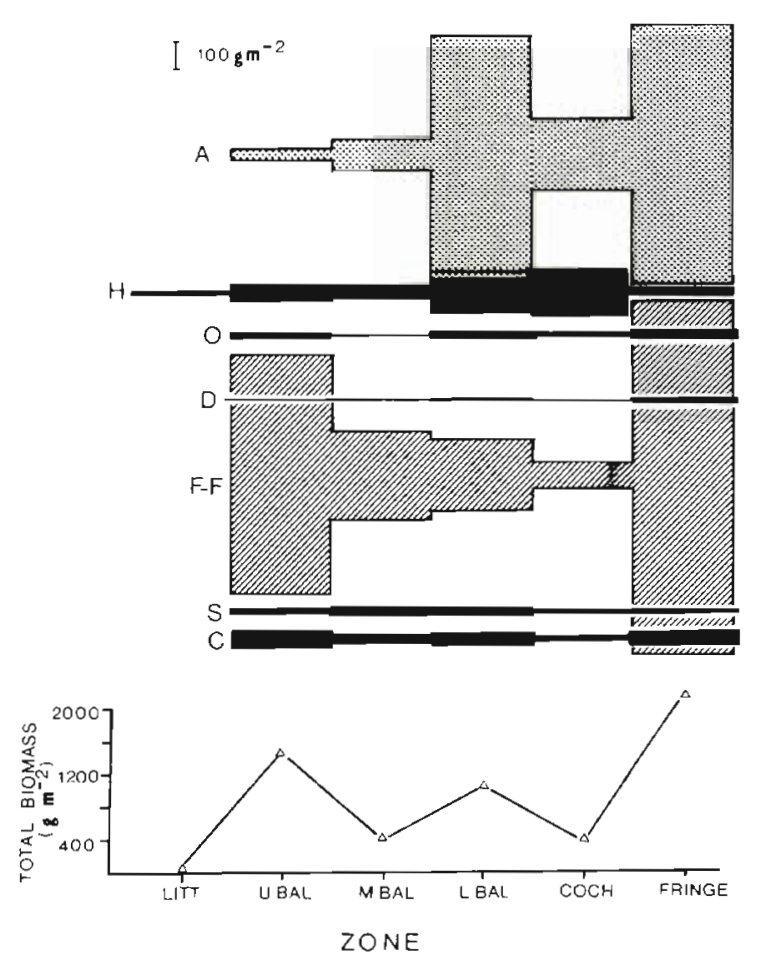

Fig. 4. Vertical distribution of total and trophic biomass on exposed shores. Legend as for Fig. 3

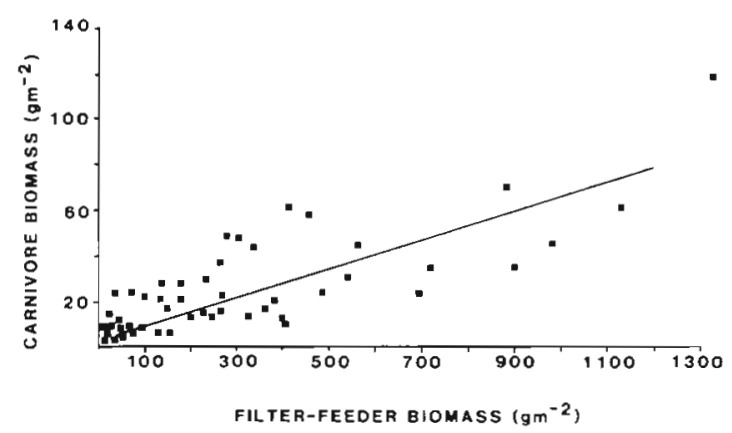

Fig. 5. Relation between carnivore biomass and filter-feeder biomass: $y=0.05 x+8.95, r=0.71$

\section{DISCUSSION}

\section{Energy flow}

There has been extensive research into the effects of wave action on single species and also on single trophic compartments such as algae (Kingsbury 1962) but its influence on the trophic structure of entire intertidal communities has only rarely been examined (MacLachlan et al. 1981, Hartnoll 1983). Our data indicate that the balance between different trophic com. partments on rocky shores is largely controlled by the degree of wave exposure experienced. While the temperature regime establishes a framework of species that are likely to be present (due to temperature-based, biogeographic) effects, the actual biomass of many important species is largely dependent on wave action (McQuaid \& Branch 1984). T-tests comparing the trophic structure of shores which differed in terms of their exposure to wave action, temperature regime and nature of substratum revealed significant differences in trophic compartment biomass only when comparisons were made between exposed and sheltered shores. There was no correlation between the number of species in a compartment and its overall biomass; but filter-feeder, carnivore, omnivore and total biomasses were all significantly greater on exposed shores.

As a result, fundamentally different patterns of energy flow may be expected on sheltered and exposed shores. Hartnoll (1983) has suggested that in areas sheltered from wave action the mid-tide community on the Isle of Man will function as a net producer while in more exposed areas the intensity of limpet grazing is greater, inhibiting the initial establishment of macroalgae so that primary production is lower and consumption by the community greatly exceeds production. In the Cape of Good Hope we failed to find a decrease in macroalgal biomass under more exposed conditions, except in the cochlear zone (Fig. 4) where, as in the case described by Hartnoll, limpet biomass increased dramatically and certainly accounted for the decline in macroalgae. But there was a shift in the balance of trophic compartments under different conditions of exposure, and on exposed shores the relative contribution of macroalgae to the total biomass decreased as filter-feeder biomass rose (Table 2). Many of the benthic herbivores do not graze directly on macroalgae but rather on microalgae and algal sporelings growing on the substratum. Consequently, macroalgal biomass is not always directly relevant to energy flow within the intertidal community and much of the material produced by macroalgae will enter food chains in the shallow subtidal through the detrital system. Nevertheless the shift from a community in which macroalgae form the largest component of biomass to one in which filter-feeders contribute a higher biomass indicates that sheltered and exposed shores must function as net producing and consuming systems respectively.

Considering the entire community we would expect sheltered shores to generate more primary productivity than is being consumed - especially as much of this productivity does not appear to be directly grazed and function as exporters of primary production. Exposed shores, however, with their high biomass of consumers, function as net importers of energy since the extensive filter-feeder populations will require a large input of energy from the water column. This leads to significantly higher total biomass on exposed 
shores. Although both carnivores and omnivores also exhibited greater biomass on exposed shores there were no significant differences between exposed and sheltered shores in the case of macroalgae or herbivores which contribute a much greater proportion of total biomass on sheltered shores. The essential difference between the 2 shore types lies in the addition of a very large filter-feeder component on exposed shores. This affects trophic groups as a whole rather than influencing the biomass of a particular species, and the species contributing to the additional filter-feeder biomass on exposed shores are different on the 2 coasts of the Cape Peninsula due to biogeographic factors (Table 3).

\section{Trophic interactions}

Paine \& Suchanek (1983) have discussed how organisms which are taxonomically very different may be functionally similar in terms of ecological processes. In this respect macroalgae and filter-feeders compete in a comparable manner, both being sessile and competing for space, and frequently covering $100 \%$ of the substratum. There appears to be direct competition for space between filter-feeders and macroalgae in some zones, filter-feeders being dominant on exposed shores. Experimental removal of filter-feeders often results in rapid colonisation by algae which are normally precluded (G. M. Branch pers. obs.). On sheltered shores where filter-feeders are sparse (Fig. 2) macroalgae constitute the largest trophic compartment. Even so, in certain zones algae may be more abundant under exposed than sheltered conditions, but generally only where filter-feeder biomass is low (Fig. $3 \& 4$ )

Many other factors influence algal biomass. The upshore decrease in macroalgae is presumably due to a gradient of increasing desiccation and high light intensities coupled with grazing (e.g. Connell 1972 , Chapman 1973, Underwood 1980, Underwood \& Jernakoff 1981). The influence of heavy grazing on algal biomass is well documented (e.g. Branch 1981, Lubchenco \& Gaines 1981, Hawkins \& Hartnoll 1983) but the exposed shores of the south coast of South Africa are unique in having a dense limpet zone low on the shore in the center of a zone normally dominated by algae. This clearly defined cochlear zone is characterized by a high biomass of Patella cochlear, with densities of up to $1600 \mathrm{~m}^{-2}$ (Branch 1975), and an abrupt reduction of algal biomass which interrupts the otherwise uniform downshore increase in algal biomass (Fig. 4).

There is no correlation between herbivore and macroalgal biomass (except for a negative correlation in the cochlear zone), and herbivore biomass is fre- quently high where there are no macroalgae present. Many of the benthic herbivores feed by rasping the substratum for microalgae rather than feeding directly on the macroalgae, and at least one species of Australian limpet (Cellana tramoserica) starves if it has access to only macroalgae (Underwood \& Jernakoff 1981). Apart from a general downshore decrease in standing crops (McQuaid 1981, 1982) we have little information on the local microalgae which have very low standing crops but may be capable of rapid turnover and apparently support many of the herbivores. Vertical gradients and changes in abundance of microalgae in New South Wales, however, do not correlate with densities of microalgal grazers (Underwood 1984).

Filter-feeder biomass is generally very low on sheltered shores, even though it still forms the third largest component of total biomass. On exposed shores it is very much larger; up to $6,533 \mathrm{~g} \mathrm{~m}^{-2}$ shell free dry weight. Filter-feeder populations may be divided into mid and upper shore populations where barnacles predominate and low shore populations dominated by mussles in conjunction with barnacles and, on some shores, the tunicate Pyura stolonifera. This is probably related to the duration of submergence in these different zones. Few if any filter-feeders are found in the cochlear zone, due to intense grazing of larvae by $P$. cochlear while filter-feeder numbers are also low in the lower balanoid zone, possibly due to competition with macroalgae.

\section{Intertidal dynamics}

There are 3 major features to this study. The first is that exposure to wave action is the only physical factor examined which influences the trophic structure of rocky shores in the Cape Peninsula. Temperature regime and the nature of the substratum have no effect except for an impoverishment of sessile forms (filterfeeders and algae) on unstable boulder beaches which can lead to domination of total biomass by mobile groups such as herbivores (e.g. Oudekraal A, Buffels Bay $B$; Table 2). The second is that the number of species present is little affected by the degree of wave action, and changes in trophic relationships are due to shifts in the biomass of certain trophic categories, not to the presence or absence of particular species. Finally, the major response to wave action is a massive increase in the proportion and absolute biomass of filter-feeders in areas exposed to strong wave action. This pattern has been described qualitatively from various parts of the world (Lewis 1964, Stephenson \& Stephenson 1972), but not quantitatively. Furthermore it has important implications for the dynamics of rocky 
shores. Branch (1984) has argued that sessile filterfeeders and algae are most likely to compete for space and can readily monopolise a habitat. This may be reflected in the small number of species of filter-feeders and algae (together averaging 25.0 species per shore) compared to the number of mobile species such as herbivores and carnivores (mean of 43.3 species per shore; Table 1). By contrast, herbivores and mobile predators compete more often for food, a resource which is much less easy to monopolize (Branch 1984).

Thus in communities dominated by filter-feeders, predators and physical disturbance play a vital role in preventing monopolisation of the habitat by a single dominant (Paine 1971, Connell 1978, Paine \& Levin 1981). Indeed we have recorded a positive correlation between filter-feeder and carnivore biomass (Fig. 5). On the other hand, in herbivore-dominated communities competitors may co-exist without exclusion of one species by another (Branch 1981, Hawkins \& Hartnoll 1983), and predators and disturbance cease to be of such importance in structuring the community and facilitating co-existence (Branch 1984).

The demonstration that on the shores of the Cape Peninsula wave action leads to shifts in the relative importance of trophic compartments by way of large increases in filter-feeder biomass thus has fundamental importance. The distinction between wave-exposed shores dominated by filter-feeders and sheltered, algal and herbivore-dominated shores may explain the present dichotomy of opinions relating to the relative importance of predation/disturbance and competition in structuring rocky intertidal shore communities (e.g. Branch 1984, Underwood \& Denley 1984).

Acknowledgement. We thank Dr. Steve Hawkins for useful suggestions during revision of the manuscript.

\section{LITERATURE CITED}

Ballantine, W. J. (1961). A biologically-defined exposure scale for the comparative description of rocky shores. Fla Stud. 1: 1-19

Branch, G. M. (1975). Intraspecific competition in Patella cochlear Born. J. Anim. Ecol. 44: 263-282

Branch, G. M. (1981). The biology of limpets: physical factors energy flow, and ecological interactions. Oceanogr. mar. Biol. A. Rev. 18: 235-380

Branch, G. M. (1984). Competition between marine organisms: ecological and evolutionary implications. Oceanogr. mar. Biol. A. Rev. 22: 429-593

Chapman, A. R. O. (1973). A critique of prevailing attitudes towards the control of seaweed zonation on the sea shore. Botanica mar. 16: 80-82

Connell, J. H. (1972). Community interactions on marine rocky intertidal shores. A. Rev. Ecol. Syst. 3: 169-192

Connell, J. H. (1978). Diversity in tropical rain forests and coral reefs. Science, N.Y. 199: 1302-1310
Fricke, A. H., Thum, A. B. (1975), Temperature recording in shallow marine environments. Trans. R. Soc. S. Afr. 41: 351-357

Greenwood, P. J. (1980). Growth, respiration and tentative energy budgets for two populations of the sea-urchin Parechinus angulosus (Leske). Estuar. coast. mar. Sci. 10 $347-367$

Griffiths, R. J. (1981). Production and energy flow in relation to age and shore level in the bivalve Choromytilus meridionalis (Kr.). Estuar. coast. Shelf Sci. 12: 101-118

Hartnoll, R. G. (1983). Bioenergetics of a limpet-grazed intertidal community. S. Afr. J. Sci. 79: 166-167

Hawkins, S. J., Hartnoll, R. G. (1983). Grazing of intertidal algae by marine invertebrates. Oceanogr. Mar. Biol. A. Rev. 21: 195-282

Kingsbury, J. M. (1962). The effect of waves on the composition of a population of attached marine algae. Bull. Torrey Bot. Club. 89: 143-160

Koop, K., Field, J. G. (1981). Energy transformation by the supralittoral isopod Ligia dilatata Brandt. J. exp. mar. Biol. Ecol. 53: 221-233

Lewis, J. R. (1964). Ecology of rocky shores. The English Universities Press, London

Lubchenko, J., Gaines, S. D. (1981). A unified approach to marine plant-herbivore interactions. I. Populations and communities. A. Rev. Ecol. Syst. 12: 405-437

McLachlan, A., Lombard, H. W., Louwrens, S. (1981). Trophic structure and biomass distribution on two East Cape rocky shores. S. Afr. J. Zool. 16: 85-89

McQuaid, C. D. (1980). Spatial and temporal variations in rocky intertidal communities. $\mathrm{Ph}$. D. thesis, University of Cape Town

McQuaid, C. D. (1981). The establishment and maintenance of vertical size gradients in populations of Littoria africana knysnaensis (Phillipi) on an exposed rocky shore. J. exp. mar. Biol. Ecol. 54: 77-89

McQuaid, C. D. (1982). The influence of desiccation and predation on vertical size gradients in populations of the gastropod Oxystele variegata (Anton) on an exposed rocky shore. Oecologia 53: 123-127

McQuaid, C. D., Branch, G. M. (1984). The influence of sea temperature, substratum and wave exposure on rocky intertidal communities: an analysis of faunal and floral biomass. Mar. Ecol. Prog. Ser. 19: 145-151

Paine, R. T. (1971). A short-term experimental investigation of resourse partitioning in a New Zealand rocky intertidal habitat. Ecology 52: 1096-1106

Paine, R. T., Levin, S. A. (1981). Intertidal landscapes: disturbance and the dynamics of pattern. Ecol. Monogr. 51: $145-178$

Paine, R. T., Suchanek, T. H. (1983). Convergence of ecologi$\mathrm{cal}$ processes between independently evolved competitive dominants: a tunicate-mussel comparison. Evolution 37 : $821-831$

Seapy, R. R., Litter, M. M. (1978). The distribution, abundance, community structure, and primary productivity of macroorganisms from two central California rocky intertidal habitats. Pacif, Sci. 32: 293-314

Shafir, A., Field, J. G. (1980). Importance of a small carnivorous isopod in energy transfer. Mar. Ecol. Prog. Ser. 3: 203-215

Stephenson, T. A., Stephenson, A. (1972). Life between tidemarks on rocky shores. W. H. Freeman, San Francisco

Underwood, A. J. (1980). The effects of grazing by gastropods and physical factors on the upper limits of distribution of intertidal macroalgae. Oecologia (Berl.) 46: 201-213

Underwood, A. J. (1984). The vertical distribution and sea- 
sonal abundance of intertidal microalgae on a rocky shore in New South Wales. J. exp. mar. Biol. Ecol. 78: 199-220

Underwood, A. J., Denley, E. J. (1984). Paradigms, explanations and generalisations in models for the structure of intertidal communities on rocky shores. In: Strong, D. R., Simberloff, D., Abele, L. G., Thistle, A. B. (ed.) Ecological communities: conceptual issues and the evidence. Princeton University Press, Princeton, p. 151-180
Underwood, A. J., Jernakoff, P. (1981). Effects of interactions between algae and grazing gastropods on the structure of a low-shore intertidal algal community. Oecologia (Berl.) 48: 221-233

Wulff, F. V., Field, J. G. (1983). Importance of different trophic pathways in a nearshore benthic community under upwelling and downwelling conditions. Mar. Ecol. Prog. Ser. $12 ; 217-228$

This paper was presented by Professor J. G. Field; it was accepted for printing on December 8, 1984 